\title{
Testing the Logic of Collective Action in the Military Burden Sharing of the Arab "Ring States" and Israel (1960-2012)
}

\author{
Dr. Ashraf Singer \\ Assistant Professor of Political Science
}

Port Said University, Faculty of Commerce, Egypt 


\begin{abstract}
Arabs and Israel have had high defense spending to mobilize their resources for wars. They had three major wars, and one minor war. Some scholars have debated the reasons for not defeating Israel, despite waging the wars collectively. The answer that not all members of the ring states value these contributions equally. The findings are that Syria attempt to free ride on the other member of the ring States from 1960 till 1979. In other words, few countries member of the Ring States did not behave in the way the theory of collective action predicts. The findings suggest that large the Ring States members are burden-sharing at a greater rate than smaller of the ring States members when looking at military burdens and in agreement with the logic of collective action.
\end{abstract}

Keywords:The Collective Action Theory, The Ring States- Israel, the Military Burden Sharing of the Arab “Ring States” and Israel. 


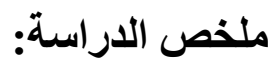

خاض العرب وإسر ائيل ثلاث حروب رئيسية مع درجة عالية من الانفاق العسكريو أعنت الدول المواجهة مع اسرائيل أن هجوم إسرائيل على أي منها يعتبر هجومـا على كل منها. والو اقع أن العلاقة بين دول المواجهة وإسرائيل هي حالة فريدة لاختبار العليد من القرضيات والإجابة على العديد من الأسئلة البحثية حول تثكيل التحالفات.وقد ناقش بعض العلماء أسباب عدم هزيمة إسرائيل، على الرغم من شن الحروب بثكل جماعي. الجواب الذي قدمته هذه الدراسـة بـان دول الطوق لم يتحملوا اعباء دفاعية على قدم

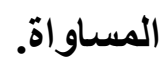

ان النتائج التي توصلت إليها الدراسة ايضا أن سوريا فضلت الاعتماد عسكرياعلي مصر وباقي دول الطوق

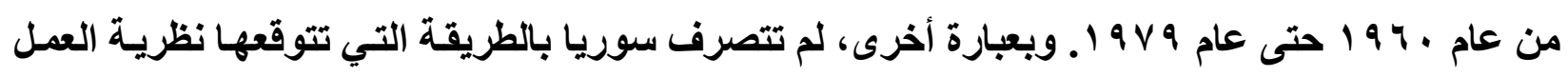

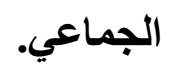




\section{1- Introduction:}

Most scholars studying issues of burden-sharing have relied on the theory of collective action to inform their work. Collective action theory looks at how actors behave in pursuit of a common goal. Burden-sharing is important because the notion ofshared risk and shared responsibility is a "founding principle of the Alliance." Resolving issuesof burden-sharing is fundamental to the continued survival of the alliance. Many studies systemically examine patterns of burden-sharing behavior within NATO. Burden-sharing can be defined as "the distribution of costs and risks among members of agroup in the process of accomplishing a common goal." (Forster and Cimbala, 2005: 1)As expected, free-riding behavior was more predominant among smaller allies. This studyaddresses a gap in the burden-sharing literature and provide relevant insights to policy-makers.

The bottom line of this paper is to investigate how the "Ring States" -Egypt, Syria, Lebanon, Jordan, -paid for security goods responded to Israeli's 's military burden behavior, and whether some countries gained benefits by free-riding the military burden of others. The Ring States declared that they considered their security to be collective and that Israel's attack on any one of them was taken as an attack on all of them. In fact, the relation of the Ring States and Israel is a unique case to test many hypotheses and answer many research questions about alliances formation.

Apparently, the data on military burden show that some countries bear a disproportionate share of the burden and criticizes other members for insufficiently defense capability. To examine the burden-sharing behavior of the "Ring States"derived from the collective action theory, that small alliance members Jordan, Lebanon will behave a free ride on the large alliance member of Egypt and Syria, from 1960 to 2012. ${ }^{1}$ To this end, this paper is divided into four sections. . In the first section, I constructed the theoretical framework offered by the collective action theory and pinpoint the significant variables related to the concept of the "free- rider", In the second section deals with data collection method and research design.In the third section describes how I analyzed the data and investigate whether Jordan and Lebanon have 
been free riding on Egypt and Syria in the security ground. in the final section, I briefly summarize the empirical results and discuss policy implications.

\section{2- A Theoretical Discussion.}

\subsection{Collective Action Theory:}

The motivation behind a collective action is that every nation is rational and will pursue a strategy that weights costs and benefits and seek to maximize expected utility.Free riding could destroy a situationin which the members of some group agree on a common objective. But individuals' motivation often encourages free riding. Obviously, individuals may try to lower costs of producing some goods that will achieve wide benefits for all groups. "The rational policy is to pursue national interest without care to the costs that might be incurred by others."(Howe, 2006:161-185)

In sum, free riding occurs for two reasons.1- An actor may hope or believe that others will do the job that the actors would like to see done. 2-An actor may fear that if one contributes toward the common good, others will ride free on those actors' efforts.(Lepgold,1998: 78-106). Clearly, the most threatening aspect for collective action is that groups intentions to behave as a free- rider will lead to collapse of collective action. Brendan Howe suggests some solutions to solve the free- rider problem. "The first solution is throw free- riders out of the community, excluding themfrom collective benefits as they refuse to pay any of the costs, and the community could able to grant exclusive private benefits to fully paid up members, the contributions of which help pay for non- excludable public benefits"(Byung-il Choi,2007: 54)

However, Neorealist theory suggests that the issue of collective action in international system is big dilemma in which there is no central authority to enforce nations to cooperate either in trade or providing public security goods.Collective- action theory allows us to highlight these incentives by identifying distinct strategic and political problems associated with the production of different security goods. The formation of alliances has been discussed and researched widely, especially for NATO members after WWII. 
(Olson and Zeckhauser,1966) give insight to the formation of alliances by assuming that a state acts rationally when it allies with the common interest of members states to oppose aggression by a common enemy. Olson and Zeckhauser considers alliances as institutions that provide the common public good of collective defense. A public good is defined as the common interest of a group of individual actors (Olson 1965; Olson and Zeckhauser 1966). " $[w]$ hen a nation decides how large a military force to provide in an alliance, it must consider the value it places in collective defense and the other nondefense goods that must be sacrificed to obtain additional military forces" (Olson and Zeckhauser 1966). In the case of NATO, they found that U.S military spending to protect Western Europe was high relative to small members who have a strong incentive to minimize their own contribution to public security goods, and they become "free riders".

They presented the idea of common security based on collective goods, and they applied this model to international alliances in which international alliances provide public goods or collective goods.(Olson and Zeckhauser,1966: 266-279)A deepempirical analysis that draw upon arguments of John Onel and Mark Elrod (1989), Chen, Feng, C Masroori(1996), .Pevehouse\& Jingang Zhao(2000), and Sorokin (1994) will be presented to examine how military burden interprets free rider behavior.Numerous research papers have reexamined the application of the collective- goods theory to the members of an alliance. "John Onel" and "Mark Elrod" (1989) were applying the collective goods explanation of NATO and other alliances. In the light of Lepgold observation that "an increase in the size of group may over time lower costs for those already in the group" (Chen, Feng, and Masroori,1966: 327)

the basic concept is that the large states provide more of public goods than smaller states, so smaller actors can free ride. "A public good is defined by two characteristics: non-rivalry and non-excludability. First, there is no rivalry between potential users of the good: one person can use it without diminishing its availability to others. Secondly, people cannot practically be excluded from using the good. Thus, it is available to everyone, whether they contributed to producing it or not."(Bodansky,2012: 651-668). 
Zyla,2016, concluded that "the imbalance of power in an alliance, there is a systematic tendency among middle powers to contribute less to the collective benefit of the public goods than they receive from it. This free riding or exploitation occurs when non-payers of the good continue to enjoy it despite their lack of payments. In such cases, the benefits of the public good were received regardless of whether payments toward it were made, which has negative effects for the collective welfare of the alliance." (Zyla,2016:9)

The collective action theory would give a solid understanding why alliances are formed against common external enemies. The major debate on formation of defense alliance is an alliance provides collective goods, but one or member or might reduce its military spending and become a free ride on others spending. Olson argues that collective action can explain "the apparent tendency for large countries to bear disproportionate shares of the burdens of multinational organizations, like the United Nations and NATO, and the continual complaints that international organizations and alliances are not given adequate (optimal) amounts of resources." (Olson,1971:36) Thus, military alliances also produce a type of public good (i.e., security for all their members), and should also present incentives for members to free ride, particularly when a large power, such as Egypt.

\subsection{Previous Analysis of the Burden Sharing:}

Chen, Masrooi, and Feng (1996) paper entitled Collective Action in the Middle East? A Study of Free Rider in Defense Spending, concluding that the Ring State until 1980s, the burden of collective military was mostly carried by Egypt as a major provider of security goods. "The empirical analysis shows that Egypt was involved in fierce arms with Israel, and little evidence that such intensive completion ever existed for Jordan, Lebanon, or Syria alone"(Chen, Masrooi, and Feng,1996: 323), and another paper also use of work done by Gerald L. Sorokin' paper entitled (1994) “Arms, Alliance, and Security Tradeoffs in Enduring Rivalries" in his seminal work, Sorokin reexamining the relationship between Egypt and Syria (1963-1988), concluding that Syrian military spending changed from negative to positive after Egypt and Israel signed a peace treaty in 1979. In other words, Syria 
increased its military spending more than Egypt in the time of non-war. Also, he concluded that in 'Pre-Camp David years, increases in Egypt's military spending had negative marginal effect on Syria military spending, indicating that Syria was able to "free-ride" on Egypt. For every million-dollar increase in Egyptian military spending, Syria reduced its spending about \$310,000. After the Camp David agreement in 1978, there was no longer an alliance between Egypt and Syria, the relationship became positive."(Sorokin, 1994: 440-441)

The collective- action theory assumes that the smaller alliance members would free-ride on larger ones. The model of collective-action will use econometrics analysis to measure the aspects of free- ride and collective action in which every state has desired to exploit its utilities based on gathering alliances to increase the level of its benefits. I would first examine systematically how defense burdening compares to that of its alliance partners.

This paper examines whether the theory of collective action explains currentburden-sharing behavior in the ring States. The problem of collective action in the Middle East emerges from Syria, Jordan, and Lebanon believing that Egypt will pay for common security according to its historical obligation and its security dilemma. Since Egypt has a long border with Israel. Egypt's population, economy, and military size were bigger than others. There is empirical evidence supporting this explanation, in which Egypt's military spending was larger than that of Syria, Jordan, and Lebanon.

Sorokin (1994) presents his evidence, for example, on the relation between Egypt and Syria: "The primary finding shows the direction of the relationship between Egyptian and Syrian arms changes from negative to positive after the alliance between them was canceled when Egypt and Israel signed the Camp David Accord" (Sorokin,1994: 440-441)Supposedly, Arabs countries have collective economic and military effectiveness, but the fact was deferent in war time. If Syria, Jordan, and Lebanon were to contribute the same level as Egypt towards the common security, there would be no free -rider. Of course, security goods are as public goods not private goods, because the provider cannot prevent others from consuming it.(Lepgold, 1998:87) 


\section{3-Empirical Methodology:}

To examine the basic empirical analysis, statistic indicators would measure the different levelof changes in military spending for each member in the Ring States. To simplify the idea of this paper, I would form this hypothesis as follows: The principal question in this paper is whether collective action, as a comprehensive and largely accepted way to explain the problem of free- rider, remains valid when explaining different kinds of free riding in the time of war and peace.

Hypothesis 1:The Ring States response positively to the increases military burden of Israel.

This paper uses percentage of military expenditures to grossdomestic product (\% GDPit) as the dependent variable and a measure of burden-sharing insteadof real defense expenditures. The most commonly used burden-sharing measure is defense expenditures as a percent of GDP because it allows us to measure the internal sacrifice a state makes to contribute to the collective effort, and to establish comparisons with other allies of different size and wealth. ${ }^{1}$ The finding will help to explain the exist of external threat, what is likelihood of Ring States members are largely cooperative in their decisions concerning levels of military spending of Israel or are largely non-cooperative.

The benefits of using the military burden comparison to investigate the relationship, either positive or negative, when including Israel as external threats, in which a few members of the Ring States were taking a free- ride on public goods without paying the cost or sharing the cost between them. Clearly, the best outcome is that all Ring States pay sufficient quantity of public goods (security goods), and the worth outcome is one actor or more pays insufficiently for public goods (security goods). This paper would examine who paid for public goods or common security where the level of Israeli's military burden as variable change presents the level of threats for the Ring States. This paper will illustrate aspects of free- riding military burden behavior.

${ }^{1}$ https://www.cpsa-acsp.ca/papers-2005/Bergeron.pdf 


\subsection{The Theoretical Model:}

By modeling the dynamics of Ring States strategy, I can study carefully the spending behavior of Ring States. The change of such level of military spending affected whether free riding behavior was present among Ring States members from the 1960 to 2012 period. This paper has utilized military spending data from 1960 to 2012, because of the necessity to include the impact of withdraw of Egypt from collective action towards Israel, and understand the change of Syria behavior military spending. Moreover, Small members of the Ring States Jordan, Lebanon, and Syria are a vital or not as Egypt in providing common security. The model of burden-sharing used in this project is indicated in the equation below:

Israel relation to the ring states $1960-2012$

$M B{ }_{t}^{I S}=\beta_{\mathrm{O}}+\beta_{1} M B_{t-1}^{E G}+\beta_{2} M B_{t-1}^{J O}+\beta_{3} M B_{t-1}^{L E}+\beta_{4} M B{ }_{t-1}^{S Y}+\varepsilon$

$M B{ }_{t}^{I S}$ Military burden of Israel (dependent variable)

$M B{ }_{t-1}^{E G}$ Military burden of Egypt (independent variable)

$M B{ }_{t-1}^{J O}$ Military burden of Jordan (independent variable)

$M B \underset{t-1}{L E}$ Military burden of Lebanon (independent variable)

$M B{ }_{t-1}^{S Y}$ Military burden of Syria (independent variable)

The theoretical model assumes that military spending of Israel is an external threat that the actors (Ring States) perceive; and I assume that the Ring States have strong alliance policies. This project examines Israeli military burden as one of the plausiblemeasures of threat.I did find that a one lag for the ring states member to response to Israel military spending give the best 
outcomes where the changes in military spending and most of actual spending arrives with delay. This study applies (OLS) analysis on data of military spending as a percentage of GDP for the Ring States and Israel ${ }^{2}$, which available at the Armament, Disarmament, and International Security (SIPIR) Stockholm International Peace Research Institute. ${ }^{3}$ The dependent variableand independent variables are expressed in constant 2005 PPP dollars.

\section{4- Data and Empirical Findings}

Many international relations' experts and economic scholars have debated the value of intra-alliance cooperation to build up a shield of protection. The logic of collective action is forming alliances and gathering military capabilities to create a balance towards threats.To test the research hypotheses, if many Ring States respond positively towards one another, it reflects the collective action; if a few members respond negatively to one another, it reflects free riding. The ordinary least squares regression (OLS) model analyzes timeseries data on the ring states members and Israel from 1960 to 2012.

The year 1960 was selected as the start pointfor major reasons. Prior to the early 1960s, there is very little reliable information concerning the yield, size, or accuracyof 1960 military spending data for the Middle-East countries. The year 2012 was selected as the endfor a reason that military spending of Syria was not accurate because of the consequence of destabilization of Syrian government.

The empirical section of this paper provides evidence supporting of the hypothesis from the model. For example, the application of free- rider among Ring States illustrate how an increase in any member of the Ring States defense burden would affect the other defense burden. If the size of coefficient of OLS positive (+) will reflect a strong evidence of an arms race, and collective action. If it is negative (-) it will reflect, free riding.

${ }^{2}$ Israel military burden is considered as threat variable in this model, if Israel military burden upset the Ring States policy makers, how they react is revealed in the exogamous variable.

${ }^{3}$ SIPRI. 2017.World Armaments and Disarmament: SIPRI Year book. Stockholm, Almquist Wiksell. 
Table (1) Descriptive Statistics:

\begin{tabular}{|l|l|l|l|l|l|}
\hline Variable & Obs & Mean & Std. Dev. & Min & Max \\
\hline Year & 53 & 1986 & 15.44345 & 1960 & 2012 \\
\hline egymb & 53 & .1182044 & .0911604 & .017681 & .310376 \\
\hline jormb & 53 & .1919394 & .1287561 & .067632 & .580109 \\
\hline lebmb & 53 & .09583 & .0737227 & .0216874 & .3694718 \\
\hline syrmb & 53 & .0988496 & .08248 & .033997 & .357041 \\
\hline isrmb & 53 &. .3944853 & .2062834 & .11923 & .846706 \\
\hline
\end{tabular}

\subsection{Checking for Multicollinearity:}

I tested the data for a variance inflation factor(VIF), the results in a table (3) show that the degree of multicollinearity is find where VIF values is (2.61)and it is lesser than 10. "The primary concern is that as the degree of multicollinearity increases, the regression model estimates of the coefficients become unstable and the standard errors for the coefficients can get wildly inflated."4

Table (2)Variance Inflation Factor(VIF)

\begin{tabular}{|c|c|c|}
\hline Variable & \multicolumn{1}{|l|}{ VIF } & 1/VIF \\
\hline egymbl & 3.29 & 0.30 \\
\hline jormbl & 3.15 & 0.31 \\
\hline lebmbl & 1.99 & 0.50 \\
\hline syrmbl & 2.00 & 0.49 \\
\hline Mean VIF & 2.61 & \\
\hline
\end{tabular}

${ }^{4}$ https://stats.idre.ucla.edu/stata/webbooks/reg/chapter2/stata-webbooksregressionwith-statachapter-2-regressiondiagnostics/ 


\subsection{Results:}

This paper has presented a theory of collective action to offer a better understanding of the Ring States military burden related to Israel military burden. The empirical analysis supports this hypothesis because increases of one percent of Israel military burden was accompanied by increase in Egypt military burden lag (1.06) percent. The results show that the relationship is statistically significant.An increase of one percent of Israel military burden was accompanied by increase in Jordan military burden lag (0.71) percent. The results show that the relationship is statistically significant.An increase of one percent of Israel military burden was accompanied by increase in Lebanon military burden lag (1.13) percent.The results show that the relationship is statistically significant.An increase of one percent of Israel military burden was accompanied by decrease in Syrian military burden lag $(-1.50)$ percent. The results show that the relationship is statistically insignificant.Except Syria, the empirical analysis does support this hypothesis that the Ring States increase military spending when Israel does. To evaluate the study hypothesis, the empirical analysis does support this hypothesis that The Ring States response positively to the increases military burden of Israel. Only Syria was in a negative relationship with Israel and statistically insignificant. So, Syria got a free ride on Egypt's military spending from 1960-1979. 
Table (3) OLS Regression estimates of "Israel Military Burden" effects on the Ring States Military Burden using REG command, 1960-2012

\begin{tabular}{|c|c|c|}
\hline $\begin{array}{c}\text { Variable in the } \\
\text { Model } \\
\text { Y= Israel Military } \\
\text { Burden }\end{array}$ & Coefficient. & $\begin{array}{c}\text { Standard } \\
\text { Errors }\end{array}$ \\
\hline egymbl & $\begin{array}{l}1.06 * \\
(2.11)\end{array}$ & .5063748 \\
\hline jormbl & $\begin{array}{c}.71 * \\
(2.26)\end{array}$ & .3163065 \\
\hline lebmbl & $\begin{array}{c}1.13 * * * \\
(3.88)\end{array}$ & .2938929 \\
\hline syrmbl & $\begin{array}{c}-.35 \\
(-1.50)\end{array}$ & .2387265 \\
\hline _cons & $\begin{array}{c}.05 \\
(1.62)\end{array}$ & .034996 \\
\hline Prob $>$ F & 0.0000 & - \\
\hline Number of Obs & 53 & - \\
\hline R-squared $\mathbf{R}^{2}$ & 0.6926 & - \\
\hline
\end{tabular}

Note: $\mathbf{t}$ statistics in parentheses

$* \mathbf{p}<0.05 ; * * \mathbf{p}<0.01 ; * * * p<0.001$

The most important finding for the long term is that collective action will not be available among Ring States members, and this suggests Israel has the chance to be preponderant among them. The results appear to be quite clear that Egypt was a main provider of security goods before 1978, and the rest of Ring States got a free ride on Egypt's military spending. However, after 1978 the Ring States free ride on the others. 
Since Egypt and Syria had collective action towards Israel in the time of war 1973, they missed the opportunity to cooperate when Egypt took unilateral action to make peace with Israel without consulting with Syria. So Syrian began gradually to reduce its alliance ties with Egyptian. For instance, "In the third week of October 1973, Sadat did not consult with other Arab Leaders, or even with his Syrian war ally for cease fire with Israel. Assad heardlike other that Sadat accepts the cease-fire on October 22, 1973, Syrian accused Egypt of defecting from Arab coalitions. Sadat went to Israel November 9, 1977 and he avoid any consultations with Arab leaders although he exchanged views with Syria president three days before his trip" ( Karawan, 1994:253)

Finally, the relationship between Egypt and Syria arms was negative after the alliance between them was canceled when Egypt and Israel signed the Camp David Accords. Jordan's military spending remains minimal and does not reflect any sort of collective action during study period. Jordan alerted its military spending towards Syria more than Israel because of -King Hussain of Jordan, in specific, perceived the growth of the Syrian power as a direct threat to his regime. Syria's support of Palestinians during their uprising against Hussain in 1970 is a piece of evidence of the hostility which has existed between the two countries for quite some time.(Chen, Masrooi, and Feng,1996:325)

\section{5- Conclusion:}

In all respects, then, we see clear evidence of a shift to free or easy riding by the

Syrian government in the defense theatre. Defense budgets as a percentage of GDP havedeclined steadily since the 1960 till the 1979.The breakup of Soviet Union influenced the amount of Syria's military spending and someone might say the sharp fall of Syria military spending after 1994 reflected a belief that Syria by herself does not have a capability to lunch war against Israel. Therefore, Syrian leadership might have assumed that the influence of the U.S over Egypt, Jordan and Israel politics would help Syria to survive without increasing its defense spending. In conclusion, the result suggests that, first; the Ring States have a path dependence on military spending. Second, The Ring States free ride on allies, but arm-race with enemies. Third, The Ring States increase military burden when Israel does so. 
By applying a collective action model would examine the Egypt's decision to sign a peace treaty with Israel in 1978.This action by Egypt reduce the freerider problem. It can be considered a rational choice, since Egypt found it was difficult to throw free riders out of collective benefits from providing public security goods. Therefore, Egypt decided to withdraw from the public good pool by signing a peace treaty with Israel in 1978. Would this example encourage Syria and Lebanon to make peace with Israel or to prefer acting out their policy as free- riders? Deciding factors is the political incentive of the leaderships in Syria and Lebanon either to support the collective action towards peace or towards war. 


\section{$\underline{\text { Reference: }}$}

Bodansky.D(2012)What's in a Concept? Global Public Goods, International Law, and Legitimacy, European Journal of International Law, Volume 23, Issue 3, pp 651-668

Choi.B and Howe.B,(2007) International Negotiations : Theory and Practice,Ewha Womans University Press,Seoul,Korea,p.54

Chen.B, Feng.Y, and Masroor.C,(1996) Collective Action in the Middle East? A study of Free-Rider in Defense Spending, Journal of Peace Research, vol. 33, p 327

Forster PK and Cimbala SJ (2005) The US, NATO and Military BurdenSharing. New York: Frank Cass.

Howe.B(2006) Rationality and Intervention in an Anarchic Society, Korean Journal of Defense AnalysisVol. 18 , Iss. 1,2006

Karawan.I(1994) Sadat and the Egyptian-Israeli Peace Revisited, International Journal ofMiddle East Studies, Vol. 26, No. 2, p.253

Lepgold.J,(1998) NATO's Post-Cold War Collective Action ProblemInternational Security, Volume 23, Number 1, pp. 78-10

Olson.M(1965), The Logic of Collective Action, Cambridge, Mass.: Harvard University Press, p.36

Olson and Zeckhauser,(1966) "An Economic Theory of Alliances", Review of Economic and Statistics, Vol.48, No.3, pp.274-278

Sorokin.G (1994) Arms, Alliance, and Security Tradeoffs in Enduring Rivalries, International Studies Quarterly, Vol.38, No.3, pp 440-441

Stockholm International Peace Research Institute (SIPRI) (2016) SIPRI Yearbook 2016: Armaments, Disarmament and International Security. New York, NY: Oxford University Press.

Zyla.B ,(2016) NATO Burden Sharing: A New Research Agenda, Journal of International Organizations Studies,7, Issue 2, p.9 


\section{Appendix (1)}

Data on Military Burden (Egypt, Jordan, Lebanon, Syria and Israel (1960-2012)

\begin{tabular}{|c|c|c|c|c|c|}
\hline Year & EGY MB & JORMB & LEBMB & SYR MB & ISR MI \\
\hline 1960 & 0.2645 & 0.2691 & 0.0371 & 0.1082 & 0.2106 \\
\hline 1961 & 0.2737 & 0.2186 & 0.042 & 0.1123 & 0.2259 \\
\hline 1962 & 0.1153 & 0.2292 & 0.0572 & 0.0944 & 0.2637 \\
\hline 1963 & 0.155 & 0.2171 & 0.047 & 0.1284 & 0.2849 \\
\hline 1964 & 0.1872 & 0.183 & 0.0483 & 0.0981 & 0.2651 \\
\hline 1965 & 0.1757 & 0.1337 & 0.051 & 0.0795 & 0.2535 \\
\hline 1966 & 0.1498 & 0.1169 & 0.0555 & 0.0987 & 0.2779 \\
\hline 1967 & 0.1589 & 0.4578 & 0.064 & 0.1372 & 0.4418 \\
\hline 1968 & 0.203 & 0.5801 & 0.0641 & 0.16 & 0.4855 \\
\hline 1969 & 0.2518 & 0.4851 & 0.0607 & 0.1105 & 0.5319 \\
\hline 1970 & 0.2804 & 0.4473 & 0.057 & 0.1096 & 0.6697 \\
\hline 1971 & 0.3025 & 0.413 & 0.053 & 0.1074 & 0.6523 \\
\hline 1972 & 0.2448 & 0.4426 & 0.0674 & 0.0441 & 0.5885 \\
\hline 1973 & 0.2421 & 0.4055 & 0.0703 & 0.0721 & 0.8247 \\
\hline 1974 & 0.3104 & 0.3313 & 0.0656 & 0.0603 & 0.7919 \\
\hline 1975 & 0.2673 & 0.304 & 0.0646 & 0.0575 & 0.8467 \\
\hline 1976 & 0.2398 & 0.3711 & 0.0426 & 0.0602 & 0.773 \\
\hline 1977 & 0.2351 & 0.269 & 0.0217 & 0.0601 & 0.6597 \\
\hline 1978 & 0.1776 & 0.224 & 0.0389 & 0.0686 & 0.6839 \\
\hline 1979 & 0.1243 & 0.2314 & 0.0882 & 0.0691 & 0.5726 \\
\hline 1980 & 0.1096 & 0.1808 & 0.3695 & 0.1195 & 0.5678 \\
\hline 1981 & 0.1275 & 0.1875 & 0.2642 & 0.317 & 0.6336 \\
\hline 1982 & 0.1274 & 0.1838 & 0.2391 & 0.3521 & 0.5765 \\
\hline 1983 & 0.1327 & 0.1841 & 0.3338 & 0.3 & 0.4958 \\
\hline 1984 & 0.1331 & 0.1633 & 0.2624 & 0.357 & 0.5344 \\
\hline 1985 & 0.1251 & 0.1723 & 0.1462 & 0.3207 & 0.4878 \\
\hline 1986 & 0.1107 & 0.1747 & 0.1197 & 0.194 & 0.4344 \\
\hline 1987 & 0.0917 & 0.1704 & 0.0248 & 0.1158 & 0.4953 \\
\hline 1988 & 0.0693 & 0.1623 & 0.0254 & 0.0753 & 0.5239 \\
\hline
\end{tabular}




\begin{tabular}{|c|c|c|c|c|c|}
\hline 1989 & 0.0543 & 0.1444 & 0.0634 & 0.079 & 0.4185 \\
\hline 1990 & 0.0522 & 0.121 & 0.1497 & 0.0639 & 0.4102 \\
\hline 1991 & 0.0543 & 0.1508 & 0.0996 & 0.0901 & 0.5202 \\
\hline 1992 & 0.0515 & 0.105 & 0.1659 & 0.072 & 0.3583 \\
\hline 1993 & 0.0475 & 0.1041 & 0.1265 & 0.0519 & 0.3735 \\
\hline 1994 & 0.0469 & 0.1008 & 0.1439 & 0.0548 & 0.3212 \\
\hline 1995 & 0.0432 & 0.0682 & 0.1356 & 0.0512 & 0.2656 \\
\hline 1996 & 0.041 & 0.0884 & 0.1122 & 0.0474 & 0.2531 \\
\hline 1997 & 0.0389 & 0.0886 & 0.0839 & 0.0486 & 0.2414 \\
\hline 1998 & 0.036 & 0.0933 & 0.0769 & 0.048 & 0.2263 \\
\hline 1999 & 0.0336 & 0.0925 & 0.0907 & 0.0526 & 0.2112 \\
\hline 2000 & $\mathbf{0 . 0 3 3 3}$ & 0.0911 & 0.0987 & 0.0542 & 0.2006 \\
\hline 2001 & 0.038 & 0.0849 & 0.0961 & $\mathbf{0 . 0 5 3 7}$ & 0.204 \\
\hline 2002 & 0.0409 & 0.0778 & 0.0851 & 0.0518 & 0.2259 \\
\hline 2003 & 0.0397 & 0.0861 & 0.0824 & 0.0594 & 0.2231 \\
\hline 2004 & 0.0351 & 0.0735 & 0.0758 & 0.0528 & 0.2101 \\
\hline 2005 & 0.0325 & 0.0676 & 0.0742 & 0.0494 & 0.188 \\
\hline 2006 & 0.0302 & 0.0685 & 0.0704 & 0.041 & 0.1771 \\
\hline 2007 & 0.0276 & 0.0878 & 0.0693 & 0.0401 & 0.1563 \\
\hline 2008 & 0.0235 & 0.0933 & 0.0572 & 0.034 & 0.1441 \\
\hline 2009 & 0.0216 & 0.1061 & 0.0627 & 0.0361 & 0.1486 \\
\hline 2010 & 0.0202 & 0.0945 & 0.0618 & 0.0354 & 0.1347 \\
\hline 2011 & 0.0189 & 0.0941 & 0.0583 & 0.038 & 0.1232 \\
\hline 2012 & 0.0177 & 0.0815 & 0.0572 & 0.0461 & 0.1192 \\
\hline
\end{tabular}


Table 4: The Ring States Members' Defense Spending as a Percentage of GDP1960-2012

\begin{tabular}{|c|c|c|c|c|c|}
\hline & $1960-1969$ & 1970-1979 & 1980-1989 & 1990-1999 & $2000-2012$ \\
\hline Egypt & 0.19 & 0.24 & 0.10 & 0.04 & $\mathbf{0 . 0 3}$ \\
\hline Jordan & 0.26 & 0.34 & 0.17 & 0.10 & 0.11 \\
\hline Lebanon & 0.05 & 0.05 & 0.18 & 0.11 & 0.09 \\
\hline Syria & 0.11 & 0.07 & 0.22 & 0.05 & 0.05 \\
\hline Israel & 0.32 & 0.70 & 0.51 & 0.31 & 0.22 \\
\hline
\end{tabular}

Source of the Military Burden Data: Stockholm International Peace Research Institute (SIPRI) (2016) SIPRI Yearbook 2016: Armaments, Disarmament and International Security. New York, NY: Oxford University Press.

Figure (1).

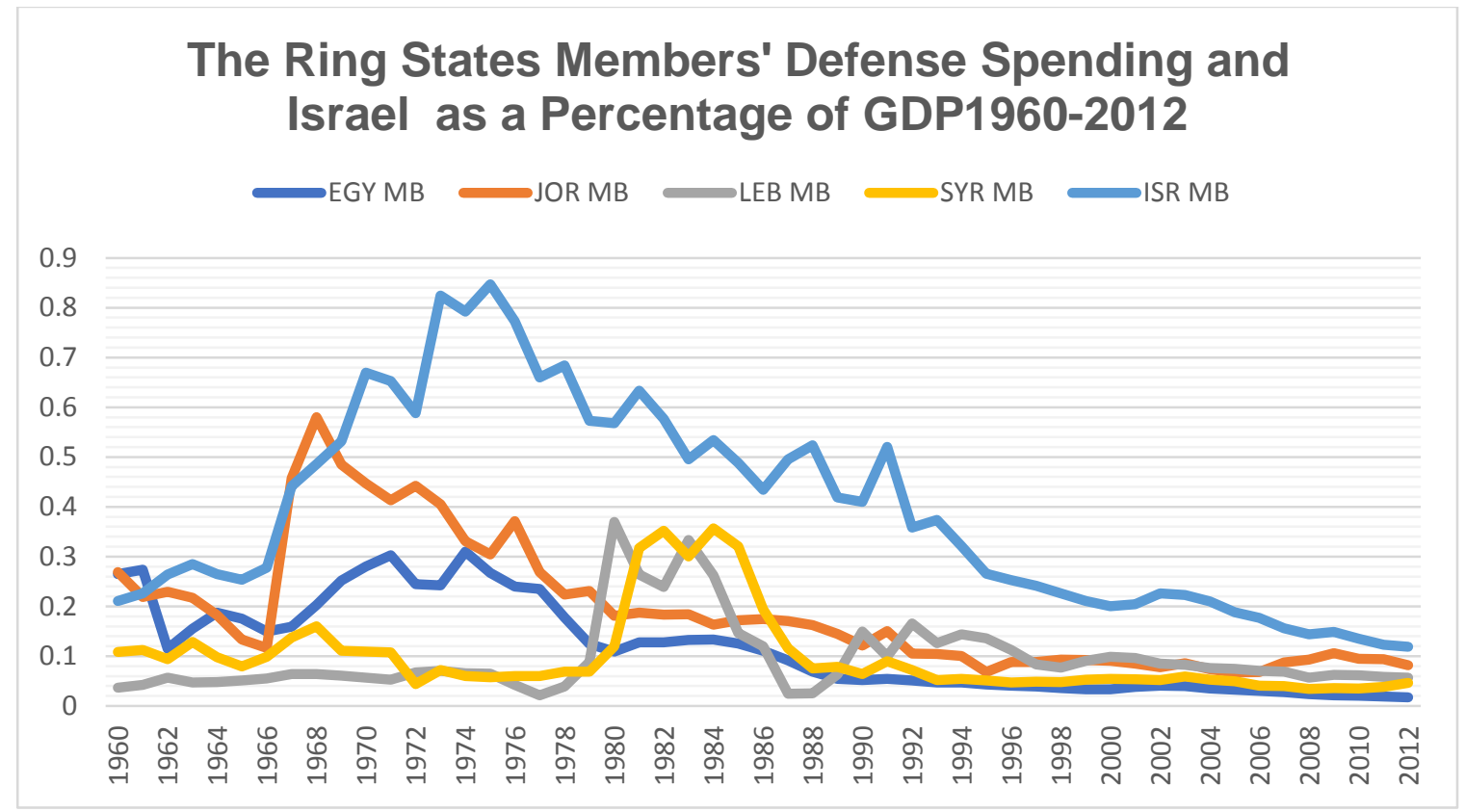

NOTES:

${ }^{1}$ Year 2012 reflects the availability of data and it is very difficult to find accurate figures about Syria 